\title{
ФРАНКОМОВНА ДРАМАТУРГІЯ ІТАЛІЙСЬКОЇ КОМЕДІЇ (1660-1697) ЯК КУЛЬТУРОЛОГІЧНИЙ ФЕНОМЕН РАННЬОГО РОКОКО
}

\section{- Данченко Марія Леонідівна}

- Аспірантка,

ORCID: 0000-0002-7846-9947, e-mail: maria.I.danchenko@gmail.com, Київський національний університет «Києво-Могилянська академія», вул. Г. Сковороди, 2, Київ, Україна, 04070

\section{- Для цитування:}

Данченко, М.Л. (2021). Франкомовна драматургія італійської комедії (1660-1697) як культурологічний феномен раннього рококо. Питання культурології, (37), 45-52. doi: https://doi.org/10.31866/2410-1311.37.2021.235996.

\section{- Анотація}

Мета статті - визначити особливості становлення стилю рококо та дослідити його культурологічну специфріку у французькій драматургії. Актуальність дослідження зумовлена відсутністю в українській культурології наукових робіт, які б висвітлювали проблематику формування стилю рококо у французькій та західноєвропейській драматургії. Також недостатньо представленим в українських наукових роботах лишається і вивчення діяльності Італійської комедії у Франції з 1660 по 1697 роки. Методологія дослідження передбачає вивчення культурної специфріки фрранкомовної драматургії Італійської комедії (1660-1697) інтердисциплінарними методами культурологічного та порівняльно-філологічного аналізу. В статті проаналізовано лінгвістичні особливості тексту першоджерела з огляду на той фракт, що з 1682 року п'єси для Італійської комедії писали сумішшю французької та італійської мов. Наукова новизна полягає у вивченні взаємодії фрранцузьких та італійських культурно-стилістичних елементів у п'єсах Анн Модюї де Фатувіля та ролі цієї взаємодії у формуванні у французькій культурі нового стилю - рококо. У дослідженні використано неперекладену п'єсу «Арлекін, імператор на Місяці» Анн Модюї де Фатувіля. Результати дослідження демонструють, що письменник вживав у п'єсі, написаній французькою мовою, італійські слова і вислови не лише для збереження італійського колориту, але і з метою досягнення комічного ефекту. Висновки. Французькі автори почали імітувати стиль італійських комедій та імпортували культурний колорит Італії, однак пом'якшували грубий гумор італійських комедій і пристосовували його до французьких смаків, заклавши цим ідеологічні основи нового стилю рококо. Анн Модюї де Фатувіль може вважатися одним із перших засновників і представників стилю літературного рококо.

Ключові слова: Італійська комедія; Анн Модюї де Фатувіль; Арлекін; рококо 


\section{- Вступ}

Драматургія Італійської комедії (1660-1697) є повністю недослідженою в Східній Європі. Цей театр був заснований мандрівною трупою італійських акторів, які спершу показували у Парижі спектаклі в традиційному італійському стилі дель арте, але з 1660 року їхня трупа мала статус офіційного театру. 31682 року італійським акторам вдалося отримати королівський привілей на дозвіл грати вистави французькою мовою. 3 огляду на цей новий статус перед італійським театральним колективом з'явилася потреба в розширенні сценічного репертуару, який тепер мав включати не лише комічні імпровізації італійською мовою, які чергувалися з музичними й вокальними сценами, а й повноцінні п'єси, які мали розуміти французькі глядачі. Відтак з 1680-х років керівництво Італійської комедії починає наймати французьких авторів, які мали писати комедії, що поєднували б у собі невимушеність італійської культурної стилістики дель арте і фрранцузьку розвинену сюжетність. Італійська трупа починає співпрацювати на постійній основі з кількома авторами, від яких вимагає зберігати в текстах італійську культурну стилістику, але, оскільки паризька публіка очікує звичних комічних сценок, французьким авторам доводиться додавати в тексти своїх комедій непристойні жарти і сцени, в яких герої можуть вдаватися до комічних імпровізацій (Mazouer, 2002). Першим з французьких письменників, який почав писати бурлескні комічні п'єси в італійському стилі фрранцузькою мовою став Анн Модюї де Фатувіль (прибл. сер. XVII-1715, руанський магістрат). Саме Анн Модюї де Фатувіль з 1682 по 1687 роки був основним автором п'єс для Італійської комедії (Cavalucci, 1936). Всі твори А. Модюї де Фатувіля були видані ще за його життя і у вигляді окремих комедій, і в загальній збірці драматургії Італійської комедії. 3 огляду на високу адміністративну посаду, яку він займав, його ім'я не вказували на обкладинках, а називали його псевдонім - Monsieur $\mathrm{D}^{* \star *}$.

\section{- Мета статті}

Мета статті - визначити особливості становлення стилю рококо та дослідити його культурологічну специфіку у французькій драматургії. Методологія дослідження передбачає вивчення культурної специфріки фрранкомовної драматургії Італійської комедії (1660-1697) інтердисциплінарними методами культурологічного та порівняльно-фрілологічного аналізу. Наукова новизна статті полягає у вивченні взаємодії французьких та італійських культурно-стилістичних елементів у п'єсах Анн Модюї де Фатувіля та ролі цієї взаємодії у фрормуванні у французькій культурі нового стилю - рококо. У дослідженні використано неперекладену п'єсу «Арлекін, імператор на Місяці» Анн Модюї де Фатувіля.

\section{- Виклад матеріалу дослідження}

Культурна специфріка п'єс А. М. де Фатувіля виразно відрізняється від творів інших фрранцузьких письменників, які писали для Італійської комедії. Так, майже всі його п'єси $є$ арлекінадами, тобто серед усіх характерних для італійської комедії дель арте персонажів головним героєм своїх творів автор завжди робить Арлекіна - найбільш грубого персонажа. Арлекінади А. М. де Фатувіля мали значний соціокультурний вплив, про що свідчить той фракт, що іменами деяких 
героїв його п'єс почали іменувати соціальні типажі. Так, «слово Грапіньян стало загальним іменем, як Гарпагон і Тартюф, а для Жан-Жака Руссо Грапіньян, прокурор і шахрай означає одне і те ж» (Furois, 1987).

Зазвичай про творчість Анн Модюї де Фатувіля згадують у контексті загальних досліджень драматургії Італійської комедії. Однією з таких робіт є монографрія П’єра-Луї Дюшартра 1924 року, присвячена історії Італійської комедії. Водночас існує дуже мало досліджень, які були б окремо присвячені творчості Анн Модюї де Фатувіля. Одним з учених, які вивчали культурологію п'єс Фатувіля, $є$ Джакомо Кавалуччі - він присвятив цьому питанню велику статтю ще в 1936 році. В наступні десятиліття твори Анн Модюї де Фатувіля у своїх роботах аналізували історики літератури Фредерік Делофр (Deloffre, 1963) і Шарль Мазуер (Mazouer, 2002), а фрілолог Люсьєнн Фюруа (Furois, 1987) в 1987 році написала детальну біографрію А. М. де Фатувіля, і уклала вичерпну бібліографію, в якій каталогізувала всі джерела, в яких сучасники згадують про творчість А. М. де Фатувіля, та перелічила всі сучасні дослідження, присвячені вивченню творів саме цього письменника. Також про творчість А. М. де Фатувіля згадує і фрранцузький культуролог Гі Боке (Boquet, 1979) в контексті свого загального дослідження репертуару Італійської комедії. Культурологи, які досліджують твори, написані для Італійської комедії, пов'язують їх появу з формуванням стилю літературного рококо, а репертуар Французької комедії відносять до напряму французького класицизму (Milam, 2011). У більшості культурологічних досліджень, присвячених вивченню репертуару італійського комічного театру XVIIXVIII ст., розглянуто цей культурний феномен в контексті фрормування традиції літературного рококо.

Для створення цього жанру французький драматург вдається у своїх сюжетах до сатиричного зображення тих соціальних явищ, з якими він був знайомий як політичний діяч. Так, він висміює фрінансистів, які удають банкрутів заради власного збагачення, вчених, які роками працюють над нікому непотрібними дослідженнями, лікарів-неуків, жінок, які розорюють своїх чоловіків (Boquet, 1979). На думку Ф. Делофрра (Deloffre, 1963), у Фатувіля соціальна сатира стає такою гострою, що її можна вважати радше чорним гумором.

Комедія «Арлекін, імператор на Місяці» - комічна історія пройдисвіта, що закохався у служницю Коломбіну, яка працює в домі вченого-педанта. Доктор дратується через те, що в нього повен дім галасливих жінок - донька, служниця і племінниця, і прагне швидше віддати заміж їх усіх. Дія п'єси починається з комічної сварки господаря-вченого (Дотторе), який розглядає у телескоп Мiсяць, зі своїм слугою П'єро, якому набридло допомагати господарю вночі з його дослідами замість того, щоб спати. Дотторе так ревно досліджує Місяць тому, що вірить, ніби там живуть люди, так само, як і на Землі. А на думку П'єро, Мiсяць нагадує не що інше, як яєчню на вісім жовтків (Monsieur $D^{* * *}, 1684$ ). Герої розмовляють між собою сумішшю італійської і французької мов:

«Le Docteur

La mia patientia fa miracola. Essayons cependant s'il est possible, de le tirer de cet entêtermen ; ascolia animale. As-tu jamais remarqué ces certaines Nuages qu'on voit autour de la Lune? Ces... 


\section{Pierrot}

J'entends, c'est-à-dire, l'ornement de l'Aumelette.

Le Docteur

L'ornement du Diable qui t'emporte: tais-toi; la malhora, \& ne songe plus à Aumelette".

[Доктор

Моє терпіння - це просто якесь чудо. Спробуймо-но, якщо це можливо, відволікти його від цієї балачки, дурну тварюку. Ти коли-небудь звертав увагу на оті хмарки, що їх видно довкола місяця? Ці...

П'єро

Я думаю, це називається білок від яєчні...

Доктор

Білок від дідька, який би тебе побрав! Замовкни, нещастя, і не думай більше про яєчню]» (Monsieur $D^{* * *}, 1684$, с. 5).

Зауважимо, що в тексті комедії Анн Модюї де Фатувіль намагається втілити культурну стилістику італійського театру, яку більшість критиків характеризує як притаманне для театру дель арте - так, актори, які виконували ролі у виставах Італійської комедії, в багатьох сценах мали імпровізувати, і це відображено в тексті самої п'єси. Автор вставляє в репліки персонажів італійські слова і речення, а італійська мова часто використовується саме тоді, коли персонаж свариться. Арлекін у п'єсах А. М. де Фатувіля є центральним персонажем, і до певного моменту він діє як спритний шахрай, який навіть викликає симпатію, проте в цьому творі його інтриги завершуються раптовою і блискавичною поразкою, яка нагадує про арешт Тартюфа у комедії Ж.-Б. Мольєра. Відтак Арлекін в автора не є позитивним персонажем. Загалом саме на матеріалі цієї комедії можемо спостерігати, що вплив фрранцузького культурного дискурсу в А. М. де Фатувіля $є$ надзвичайно виразним, оскільки автор веде із фрранцузькими класиками, яких цитує в своїй п'єсі, своєрідний діалог - він прямо згадує кілька комедій Мольєра. Варто також підкреслити і той факт, що зазначеній п'єсі притаманне таке явище, як критика французьких суспільних звичаїв, що не було властивим творам з репертуару Італійської комедії та для рокайльної драматургії загалом.

Арлекін після кількох невдалих спроб проникнути у дім доктора врешті вирішує видати себе за посланця імператора Місяця і посватати цього разу вже доньку вченого. У образі імператорського посла розповідає про звичаї мешканців Місяця, кажучи, що вони достоту такі ж, як і у землян: «Кожен намагається влаштувати свої справи якомога вигідніше завдяки своєму ближньому, і найбільша чеснота у моїй державі - це мати багато майна» (Monsieur D***, 1684). На запитання доктора про те, чи є на Місяці вчені, Арлекін каже, що в них ціла група науковців уже сімдесят років працює над словником, який не можуть закінчити упродовж двох століть. Судді там теж продажні, бо беруть подарунки через своїх дружин, а чоловіки - вельми зручні у поводженні, лихварі беруть від сиріт у заставу останнє срібло, а жінки розпоряджаються всіма грішми, і витрачають геть усе, встають по обіді, витрачають по три години на свій туалет, а потім їдуть у кареті в Оперу, у Комедію, або на прогулянку (Monsieur $\left.D^{* \star *}, 1684\right)$. Після цього вони їдуть до когось вечеряти, а потім на бал, звідки повертаються о четвертій 
чи п'ятій годині ранку, і лягають спати у своїх апартаментах окремо від чоловіків, які можуть не бачити дружин по кілька тижнів. Всі присутні разом вигукують, що на Місяці все точно так, як і у них. Зрештою, до господаря дому прибуває посланець із листом, в якому справжні наречені дівчат, до яких залицявся Арлекін, викликають його на дуель. Його перемагають, і той у відповідь зрікається їх усіх дівчат, а кавалери одружуються зі своїми обранками.

\section{- Висновки}

П'єса Анн Модюї де Фатувіля «Арлекін, імператор на Місяці» $є$ зразком синтезу італійського та французького культурних дискурсів. Автор намагався імітувати італійську культурну стилістику в тому її аспекті, як її сприймали фрранцузькі глядачі - подібно до комічних вистав, в яких дозволялося використовувати непристойні жарти. Для того, щоб надати своїм п'єсам відповідної сюжетної гостроти, Анн Модюї де Фатувіль вдавався у своїх творах до гострої соціальної сатири, критикуючи французькі суспільні звичаї, що не було властивим напряму традиційної італійської комедії. Водночас Анн Модюї де Фатувіль став першим автором, який цілеспрямовано намагався збагатити сюжети драматургії Італійської комедії - він надавав героям певного психологізму, модифрікував традиційні для італійської комедії акторські амплуа та цитував у своїх п'єсах Ж.-Б. Мольєра й інших фрранцузьких класиків.

За стилістикою п'єси Анн Модюї де Фатувіля ще не можна вважати зразками літературного рококо, але саме він перший драматург, який цілеспрямовано створював новий літературний і культурний стиль, що мав об'єднувати стилістичні риси італійського та французького походження, і саме орієнтація на такий стилістичний космополітизм згодом стане основною рисою стилю фрранцузького літературного рококо.

\section{- Список використаних джерел}

Boquet, G. (1979). Les Comédiens Italiens à Paris au temps de Louis XIV. Revue D'Histoire Moderne \& Contemporaine, 26(3), 422-438. https://doi.org/10.3406/ rhmc. 1979.1065

Cavalucci, G. (1936). Fatouville, auteur dramatique. Revue D'Histoire Littéraire De La France, 43(4), 481-512. https://www.jstor.org/stable/40520323?seq=1

Deloffre, F. (1963). Aspects inconnus de l'ancien théâtre italien. Cahiers De L'Association Internationale Des Etudes Françaises, (15), 177-188. https://doi.org/10.3406/ caief.1963.2253

Duchartre, P. L. (2012). The Italian Comedy [Monograph] (R. T. Weaver, Trans.). Dover Publications, Inc. https://cutt.ly/rnzh6tY

Furois, L. (1987). Mise au point sur la personnalité de Fatouville. Scuola Superiore di Lingue Moderne per Interpreti e Traduttori, Nuova Serie, 2, 169-176. http://hdl.handle. net/10077/9554

Mazouer, C. (2002). Le théâtre d'Arlequin: comédies et comédiens italiens en France au XVIle siècle [Monographie]. Presses de l'Université de Paris-Sorbonne. https://cutt. ly/mnzjdez

Milam, J. D. (2011). Historical Dictionary of Rococo Art. Scarecrow Press. https://cutt.ly/7nzjcuH 
Monsieur $D^{* * *}$. (1684). Arlequin Empereur dans la Lune: Comédie. A Troyes: Chez Garnier, Imprimeur Libraire, rue du Temple. https://gallica.bnf.fr/ark:/12148/bpt6k853786v

\section{- References}

Boquet, G. (1979). Les Comédiens Italiens à Paris au temps de Louis XIV [Italian comedians in Paris in the time of Louis XIV] Revue D'Histoire Moderne \& Contemporaine, 26(3), 422-438. https://doi.org/10.3406/rhmc.1979.1065 [in French].

Cavalucci, G. (1936). Fatouville, auteur dramatique [Fatouville, dramatic author] Revue D'Histoire Littéraire De La France, 43(4), 481-512. https://www.jstor.org/ stable/40520323?seq=1 [in French].

Deloffre, F. (1963). Aspects inconnus de l'ancien théâtre italien [Unknown aspects of ancient Italian theatre]. Cahiers De L'Association Internationale Des Etudes Françaises, (15), 177-188. https://doi.org/10.3406/caief.1963.2253 [in French].

Duchartre, P. L. (2012). The Italian Comedy [Monograph] (R. T. Weaver, Trans.). Dover Publications, Inc. https://cutt.ly/rnzh6tY [in English].

Furois, L. (1987). Mise au point sur la personnalité de Fatouville [Clarifications about the development of Fatouville's personality] Scuola Superiore di Lingue Moderne per Interpreti e Traduttori, Nuova Serie, 2, 169-176. http://hdl.handle.net/10077/9554 [in French].

Mazouer, C. (2002). Le théâtre d'Arlequin: comédies et comédiens italiens en France au $X V I l e$ siècle [Theatre of Arlequin : Italian comedies and comedians in France in XVII century] [Monograph]. Presses de l'Université de Paris-Sorbonne. https://cutt.ly/ mnzjdez [in French].

Milam, J. D. (2011). Historical Dictionary of Rococo Art. Scarecrow Press. https://cutt. ly/7nzjcuH [in English].

Monsieur D*** (1684). Arlequin Empereur dans la Lune [Arlequin Empereor on the Moon]: Comedy. Troyes: Garnier, imprimeur Libraire, rue du Temple. https://gallica.bnf.fr/ ark:/12148/bpt6k853786v [in French].

\section{- FRENCH-LANGUAGE DRAMA OF THE COMéDIE-ITALIENNE (1660-1697) AS A CULTURAL PHENOMENON OF EARLY ROCOCO}

\section{- Mariia Danchenko}

- PhD student,

ORCID: 0000-0002-7846-9947, e-mail: maria.I.danchenko@gmail.com,

National University of Kyiv-Mohyla Academy,

Kyiv, Ukraine

\section{Abstract}

The purpose of the article is to determine the peculiarities of the development of the Rococo style and to study its culturological specificity in French drama. The relevance of the study is determined by the lack of scientific research in the Ukrainian cultural studies 
that would elucidate the issues of the Rococo style development in the French and Western European drama. Also, the study of the Italian comedy in France from 1660 to 1697 remains insufficiently represented in Ukrainian scientific works. The research methodology involves the study of the cultural specificity of the French-language drama of the Italian comedy (1660 1697 ) by interdisciplinary methods of cultural and comparative philological analysis. The article analyses the linguistic features of the original text, taking into account the fact that since 1682 plays for the Italian comedy were written in a mixture of French and Italian languages. The scientific novelty lies in the study of the interaction of French and Italian cultural and stylistic elements in the plays of Ann Mauduit de Fatouville and the impact of this interaction on the development in French culture of a new style - the Rococo style. The untranslated play Arlequin, Empereur dans la Lune by Ann Mauduit de Fatouville was used in the study. The results of the study show that the writer used Italian words and expressions in a play written in French not only to preserve the Italian flavour, but also to achieve a comic effect. Conclusions. The French authors began to imitate the style of Italian comedies and imported the cultural flavour of Italy, however, at the same time softened the rough humour of the Italian comedies and adapted it to the French tastes, thus laying the ideological foundations of the new Rococo style. Ann Mauduit de Fatouville can be considered one of the first founders and representatives of the literary Rococo style.

Keywords: Comédie-Italienne; Ann Mauduit de Fatouville; Arlequin; Rococo

\section{ФРАНКОЯЗЫЧНАЯ ДРАМАТУРГИЯ ИТАЛЬЯНСКОЙ КОМЕДИИ (1660-1697) КАК КУЛЬТУРОЛОГИЧЕСКИЙ ФЕНОМЕН РАННЕГО РОКОКО}

\section{- Данченко Мария Леонидовна}

- Аспирантка,

ORCID: 0000-0002-7846-9947, e-mail: maria.I.danchenko@gmail.com, Киевский национальный университет «Киево-Могилянская академия», Киев, Украина

\section{Аннотация}

Цель статьи - определить особенности становления стиля рококо, а также исследовать его культурологическую специфику во французской драматургии. Актуальность исследования обусловлена отсутствием в украинской культурологии научных исследований, которые бы освещали проблематику формирования стиля рококо во французской и западноевропейской драматургии. Также недостаточно представленным в украинских научных работах остается и изучение деятельности Итальянской комедии во Франции с 1660 по 1697 годы. Методология исследования предполагает изучение культурной специфики франкоязычной драматургии Итальянской комедии (1660-1697) при помощи интердисциплинарных методов культурологического и сравнительно-филологического анализа. В статье проанализированы лингвистические особенности текста первоисточника ввиду того обстоятельства, что с 1682 года пьесы 
для Итальянской комедии писали на смеси итальянского и французского языков. Научная новизна статьи заключается в изучении взаимодействия французских, а также итальянских культурно-стилистических элементов в пьесах Анн Модюи де Фатувиля и роли этого взаимодействия в формировании во французской культуре нового стиля рококо. Для данного исследования мы используем непереведенную пьесу «Арлекин, император на Луне» Анн Модюи де Фатувиля. Результаты исследования демонстрируют, что писатель употреблял в пьесе, написанной на французском языке, итальянские слова и выражения не только для сохранения итальянского колорита, но и с целью достижения комического эффекта. Выводы. Французские авторы начали имитировать стиль итальянских комедий, а также импортировали культурный колорит Италии, однако, при этом смягчали грубый юмор итальянских комедий, и подстраивали его под французские вкусы, заложив этим идеологические основы нового стиля рококо. Анн Модюи де Фатувиль может считаться одним из первых основателей и представителей стиля литературного рококо.

Ключевые слова: Итальянская комедия; Анн Модюи де Фатувиль; Арлекин; рококо 